\title{
Revision of Undergraduate Engineering Curriculum with Emphasis on Project-Based Teaching Learning Approach- Case Study of KTU
}

\author{
Abhilash Suryan', V Radhakrishnan', G Ramachandran ${ }^{3}$, M Abdul Rahman', Kuncheria P Isaac \\ ${ }^{1}$ Department of Mechanical Engineering, College of Engineering Trivandrum, Thiruvananthapuram, Kerala. \\ ${ }^{2}$ Adviser, Academics, APJ Abdul Kalam Technological University, Thiruvananthapuram, Kerala. \\ ${ }^{3}$ Adviser, Curriculum Development, APJ Abdul Kalam Technological University, Thiruvananthapuram, Kerala. \\ ${ }^{4}$ Ex-Pro-Vice Chancellor, APJ Abdul Kalam Technological University, Thiruvananthapuram, Kerala. \\ ${ }^{5}$ Ex-Vice Chancellor, APJ Abdul Kalam Technological University, Thiruvananthapuram, Kerala. \\ 'suryan@cet.ac.in
}

\begin{abstract}
APJ Abdul Kalam Technological University in Kerala was founded in the year 2014. The University has introduced many path breaking initiatives for modernizing and upgrading technical education in Kerala. Extensive consultations were held for the preparation of the new curriculum for the University with various stake holders including eminent academicians, distinguished industrialists, faculty members from affiliated institutions and representatives of students. A detailed survey of the existing curricula in all the universities in Kerala was conducted prior to the preparation of the curriculum for the Technological University. This paper presents certain novel features introduced by the University at its inception in the curriculum for the undergraduate programmes in engineering.
\end{abstract}

Keywords: Kerala, curriculum design, technological university, sustainable engineering, design engineering, student projects

\section{Introduction}

Technical Education has a significant role in human resource development of a country in creating capable, knowledgeable and skilled manpower,

\footnotetext{
Abhilash Suryan

Department of Mechanical Engineering,

College of Engineering Trivandrum, Thiruvananthapuram,Kerala suryan@cet.ac.in
}

enhancing industrial productivity and improving the quality of life of the people [1]. APJ Abdul Kalam Technological University also known as KTU is an institution under the Government of Kerala which has come into existence on 21st May, 2014. Since inception, the KTU has been striving to improve academic standards of the colleges affiliated to the University offering undergraduate, post graduate and research programmes in engineering, science, technology and management. There is a significant increase in the number of students graduating from the technical institutions in Kerala. There were 183 engineering colleges in the State with a sanctioned intake of 60,376 in 2016 [2].

One of the primary tasks undertaken by the University was to design an undergraduate engineering curriculum in tune with the demands of rapidly evolving employment markets and the requirements for the promotion of entrepreneurial skills among the aspiring technocrats [3]. The present paper discusses some of the major highlights of the undergraduate curriculum introduced by the University at its inception under the following sections:

- Two new courses in first year

- Acourse on life skills

- Micro-projects and remedial courses

- Practical courses associated with every course in first year 
- Activity points to promote co-curricular and extracurricular activities

- Design project in fifth semester

- More time for UG projects

- Comprehensive examination during pre-final year

- Minor program in Engineering

- Break in study for entrepreneurial pursuits for deserving students

\section{New Courses in First Year}

The University has introduced two new courses in the freshman year of the undergraduate program. The courses are Introduction to Sustainable Engineering in the first semester and Design and Engineering in the second semester [4]. Both these courses are part of curriculum for all the branches.

\section{A. Introduction to Sustainable Engineering, BE103}

Engineers of the 21st century are required to design for sustainability. Every engineering discipline ranging from Civil Engineering to Computer Science is engaged in sustainable design in one way or the other [5]. Introduced as a three credits course with three hours per week, BE103 blends theory and practice of sustainable engineering. The objectives of the course are to impart awareness on the need for sustainable development and the role of engineering and technology in ensuring the same, to familiarize the students with environmental agreements, protocols, legislations, acts, norms, regulations and rules at global, national and local level and to prepare the students to pursue the projects with due consideration for sustainable development [4].

\section{Table 1: Course Outcomes for BE103}

\begin{tabular}{|l|l|}
\hline BE103.1 & $\begin{array}{l}\text { Recognize the need for sustainable } \\
\text { development and summarize the } \\
\text { multilateral environmental agreements } \\
\text { and norms, rules and regulations at } \\
\text { national and state level. }\end{array}$ \\
\hline BE103.2 & $\begin{array}{l}\text { Identify the significant environmental } \\
\text { pollution issues and proble ms at local, } \\
\text { national and global level. }\end{array}$ \\
\hline BE103.3 & $\begin{array}{l}\text { Perform life cycle analysis of products } \\
\text { and environmental impact assessment } \\
\text { of small projects. }\end{array}$ \\
\hline
\end{tabular}

\begin{tabular}{|l|l|}
\hline BE103.4 & $\begin{array}{l}\text { Explain the basic concepts for energy } \\
\text { efficient habitats and buildings and } \\
\text { renewable and sustainable energy } \\
\text { technologies. }\end{array}$ \\
\hline BE103.5 & $\begin{array}{l}\text { Describe the basic concepts of green } \\
\text { engineering. }\end{array}$ \\
\hline BE103.6 & $\begin{array}{l}\text { Apply the concepts learned to minor } \\
\text { sustainable engineering projects. }\end{array}$ \\
\hline
\end{tabular}

The intended course outcomes for BE103 are summarised in Table 1. Prescribed assessment methods are conventional, with internal tests and assignments. However, micro-projects can be performed during practical sessions with initiatives from the faculty and the institution.

\section{B. Design and Engineering, BE102}

A course on Design and Engineering is introduced with a four hour per week schedule consisting of two theory and two practical hours. The course has three credits. The purpose of this course is to excite the student on creative design and its significance, to make the student aware about the processes involved in design, to make the student understand the interesting interaction of various segments of humanities, sciences and engineering in the evolution of a design, to get an exposure as to how to engineer a design [4]. The expected outcomes for the students on successful completion of the course are listed in Table 2.

\section{Table 2: Course Outcomes for BE102}

- Appreciate different elements involved in good designs and apply those in practice when called for.

- Aware of product oriented and user oriented aspects that make the design a success.

- Capable to think of innovative designs incorporating different segments knowledge gained in the course

- Have a broader perspective of design covering function, cost, environmental sensitivity, and safety

Assessment methods suggested include both open and closed book internal tests. The students can be assessed based on the ability to list or sketch down the design requirements for a given product, application or need to satisfy the end user or customer requirements. For the open book tests, the students may be permitted to bring three to four books such as lecture notes, own notes, data books, text books or 
reference books. But, the use of internet or mobile phones should not be allowed. Assignments may cover specific designs, sketching of a design or short write ups on design details of products. Two mini projects shall be assigned for internal assessment; one group project involving three to four students and the other individual project. Projects are to be undertaken during the practical hours. Group projects shall also be assessed at the individual level.

\section{Life Skills}

Placing special emphasis on the grooming of a well-rounded personality, a course on Life Skills is introduced as HS210 in the second year with a four hour per week schedule consisting of two theory and two practical hours. This course also has three credits. The objectives of the course are:

- To develop communication competence in prospective engineers.

- To enable them to convey thoughts and ideas with clarity and focus.

- To develop report writing skills.

- To equip them to face interview \& Group Discussion.

- To inculcate critical thinking process.

- To prepare them on problem solving skills.

- To provide symbolic, verbal, and graphical interpretations of statements in a problem description.

- To understand team dynamics \& effectiveness.

- To create an awareness on Engineering Ethics and Human Values.

- To instil Moral and Social Values, Loyalty and also to learn to appreciate the rights of others.

- To learn leadership qualities and practice them.

Expected course outcomes are [6]:

- Communicate effectively.

- Make effective presentations.
- Write different types of reports.

- Face interview and group discussion.

- Critically think on a particular problem.

- Solve problems.

- Work in Group and Teams

- Handle Engineering Ethics and Human Values.

- Become an effective leader.

The classes will mainly involve practical sessions for sharpening and fine tuning the different skills as per the objectives. The progress of each student shall be monitored on a continuous assessment mode. For example, how the student learns and practice the engineering ethics and human values can be assessed through a series of activities within the course framework, connected with socially relevant projects. The cases with current relevance may be chosen so that the students shall be familiar with the case. The evaluation for the course consists of three parts of internal evaluation at the institution level and two parts of external evaluation at the university level. In the first part of the internal evaluation, students shall be trained and assessed for capabilities in group discussion. Second part involves training and assessment in presentation skills and the final part consists of written communication skills such as letter or report writing. The external examination will include short answer questions and a case study from the contents of the syllabus and course plan for the course.

\section{Micro-Projects and Remedial Courses}

Thousands of students are admitted to the engineering programs affiliated to the University every year. Within this group, the capability, skill sets and requirements of the students vary significantly [7]. Considering this diverse nature of the requirements of the students joining Engineering programs, the University has introduced the micro projects and remedial courses.

Micro-projects involve small projects which can be attempted by first year students with their level of knowledge and skills with the guidance from faculty mentors. Students who join engineering out of their passion for the same are familiar with execution of 
small projects at the school level. Micro projects are introduced to nurture and promote such capabilities of the students from their freshman year itself. It is introduced in the first and second semesters. Two to three hours are available per week.

For Bridge/Remedial Course, diagnostic tests are to be conducted at the institution level to identify the training requirements of each student. The students may be advised to attend the appropriate bridge or remedial programme organized by the institution. The nature of the programmes can vary from institution to institution based on the requirements of the students. For example, students in one institution may require a remedial programme on language and communication ability, while the students from another institution may require a bridge course on Mathematics. Those students whose performance is outstanding in all diagnostic tests may be advised to take up micro projects under the guidance of faculty mentors. Micro projects can also be conducted in association with both BE102 and BE103 courses mentioned in previous section. Students shall attempt micro projects in sustainable engineering or design of products.

\section{Practical Courses}

Underlining the importance of practical courses in engineering curriculum, the University has introduced practical courses associated with almost every course in the first and second semester of the undergraduate programs. This is in line with the best practices followed in some reputed National institutions and Universities abroad. Previously the curriculum for the first year mainly consisted of theory courses. In the curriculum proposed for KTU, Introduction to Civil Engineering and Basics of Civil Engineering is coupled with the Civil Engineering Workshop. Similarly, Introduction to Mechanical Engineering and Basics of Mechanical Engineering is associated with the Mechanical Engineering Workshop and the Introduction to Chemical Engineering is clubbed with the Chemical Engineering Workshop. The students having Introduction to Computing and Problem Solving in the first semester curriculum, also have the Computer Science Workshop and so on. Altogether a student is imparted training in four Engineering workshop courses associated with the theory courses on the basics of engineering in the first two semesters. Similarly for the basic science courses also a theorypractical coupling is enabled with, Engineering
Physics and Engineering Physics Lab and Engineering Chemistry and Engineering Chemistry Lab. In addition to these, CAD Practice lab and Language Lab is also prescribed in the alternate weeks.

A continuous internal assessment is proposed for all practical courses. Precious academic hours were seen to be lost with the external evaluation system practised previously, with a large number of teachers traveling from institution to institution to conduct practical examinations. Prescribing a uniform set of experiments or tests for thousands of students from more than 150 institutions throughout the state could kill versatility and diversity in the practical courses. Hence the syllabi prescribe a broad outline within which the practical courses should be conducted in each institution. Within this outline, the institutions and academicians can attempt innovative course design for their practical courses. This aims to generate a healthy competition among forward thinking institutions in improving the practical course content delivery. With this, the onus of maintaining the highest quality in the conduct and assessment of practical courses has been placed on the institutions.

Assessment method for Laboratory /Practical /Workshop courses involve i) Regular Evaluation of Practical records /Outputs 60 marks ii) Regular class Viva 10 marks iii) Final practical test/written test/quiz 30 marks. Successful completion of these assessments are mandatory to earn credits for the practical courses. If the students are not able to complete some of these requirements as per the regular schedule due to some valid reason, they have to complete the same during available free time in consultation with the faculty members. If, by some reason, a student is not able to complete the requirements for earning the credits for the Practical/Laboratory/ Workshop courses by the end of a semester, grade I (incomplete) will be awarded against the course and the final grade shall be awarded only after all requirements are met. Although each of these evaluations are internally done, the institutions may bring in experts from industries or academia for external assessment and to showcase the capabilities of their students in practical engineering.

\section{Activity Points}

To be an engineer capable of competing globally and to engage socially, in addition to technical knowledge and skills, students should develop excellent soft skills, nurture team work and leadership 
qualities and have an entrepreneurial and trail blazing outlook. To achieve this, in addition to academics, students are to actively engage in co-curricular and extracurricular activities. Most of these activities have been in practice in professional education institutions in one form or the other. The university has introduced a point system for incentivising and promoting such activities.

Table 3 : Student Activity Points [8]

\begin{tabular}{|c|c|c|}
\hline \multicolumn{3}{|c|}{ I National Level Activities } \\
\hline Activity & $\begin{array}{l}\text { Max. } \\
\text { Points }\end{array}$ & $\begin{array}{c}\text { Minimum } \\
\text { Duration }\end{array}$ \\
\hline $\begin{array}{l}\mathrm{NSO} \\
\mathrm{NCC} \\
\mathrm{NSS}\end{array}$ & 70 & $\begin{array}{c}2 \\
\text { Semesters }\end{array}$ \\
\hline \multicolumn{3}{|c|}{ II College Level Activities } \\
\hline $\begin{array}{l}\text { Active Member/Office } \\
\text { bearer of Professional } \\
\text { Societies } \\
\text { (Student Chapters) }\end{array}$ & $30 / 40$ & $\begin{array}{c}4 \\
\text { Semesters }\end{array}$ \\
\hline $\begin{array}{l}\text { Elected Office bearer of } \\
\text { Student forums }\end{array}$ & 30 & $\begin{array}{c}2 \\
\text { Semesters }\end{array}$ \\
\hline $\begin{array}{l}\text { Member/Captain- } \\
\text { College Athletic/ Games } \\
\text { teams }\end{array}$ & $20 / 30$ & $\begin{array}{c}2 \\
\text { Semesters }\end{array}$ \\
\hline $\begin{array}{l}\text { Executive Member of } \\
\text { Student Clubs }\end{array}$ & 20 & $\begin{array}{c}2 \\
\text { Semesters } \\
\end{array}$ \\
\hline $\begin{array}{l}\text { Volunteer for important } \\
\text { College functions }\end{array}$ & 20 & $\begin{array}{c}2 \\
\text { Semesters } \\
\end{array}$ \\
\hline $\begin{array}{l}\text { Committee member/ } \\
\text { Organizer of Tech } \\
\text { Fest/Cultural } \\
\text { Fest/Conference }\end{array}$ & $20 / 30$ & $\begin{array}{c}2 \\
\text { Semesters }\end{array}$ \\
\hline $\begin{array}{l}\text { Placed within top } 3 \text { in } \\
\text { Paper presentation/ } \\
\text { debate/cultural } \\
\text { competitions etc. }\end{array}$ & 30 & \\
\hline $\begin{array}{l}\text { Placed within top } 3 \text { in } \\
\text { State level Sports/ } \\
\text { Games }\end{array}$ & 30 & \\
\hline
\end{tabular}

\begin{tabular}{|l|l|c|}
\hline \multicolumn{3}{|c|}{ III Entrepreneurship } \\
\hline Code & \multicolumn{1}{|c|}{ Activity } & Points \\
\hline EA1 & Any Creative Project execution & 40 \\
\hline EA2 & Awards for Projects & 60 \\
\hline EA3 & Initiation of Start-ups & 60 \\
\hline EA4 & Attracted Venture Capital & 80 \\
\hline EA5 & Filed a Patent & 80 \\
\hline EA6 & Completed Prototype Development & 80 \\
\hline & \multicolumn{1}{|c|}{ IV Self Initiatives } \\
\hline SA1 & Attend a National Conference & 20 \\
\hline SA2 & Attend an Int. National Conference & 30 \\
\hline SA3 & $\begin{array}{l}\text { Published/ got an Award for a } \\
\text { Technical paper }\end{array}$ & $30 / 40$ \\
\hline SA4 & $\begin{array}{l}\text { Organiser of student level } \\
\text { Tech. Conference/Competition }\end{array}$ \\
\hline SA5 & Foreign language skills & 30 \\
\hline SA6 & Online courses taken and completed & 50 \\
\hline
\end{tabular}

On getting a minimum of 100 activity points the student passes the course and earns 2 credits which do not count for the CGPA but mandatory for the award of the degree.

Activities that a student can engage in and the maximum quantum of points that can be earned from them are listed in Table 3 . The activity points mentioned in the current paper are the ones originally proposed. The points may be awarded to more activities deemed relevant from time to time. Additional activities could be included in the list with the approval of the Academic Committee.

\section{Fifth Semester Design Project}

Another novel feature of the curriculum is the introduction of Design Project course in the fifth semester. The course objectives [6] are:

- to understand the engineering aspects of design with reference to simple products;

- to foster innovation in design of products, processes or systems and

- to develop design that add value to products and solve technical problems.

Each student or a group of students has to take up a design project. The topic has to be decided in 
consultation with any faculty member in the department. The project evaluation has two stages. Two progress evaluations, each carrying twenty marks and a final project evaluation and presentation for sixty marks. The project supervisor and two other faculty members from the same or any other department, nominated by the Head of the Department form the evaluation board.

The course plan comprises of preliminary study and the design exercise. As part of the preliminary study, a minimum of three simple products, processes or techniques in the concerned branch of study may be shortlisted for analysis and subsequent presentation. The analysis shall focus on functionality, strength, material, manufacture/ construction, quality, reliability, aesthetics, ergonomics, safety, maintenance, handling, sustainability, cost etc. as applicable to the chosen project. Each student in the group has to present individually; choosing different products, processes or techniques.

In the design part of the project, the team may identify an innovative product, process or technology and proceed with detailed design. On the completion of the project, the team has to prepare a project report and make a presentation and defend the work. One hour per week is allotted as tutorial hour for discussions and presentations related to the Design Project. The project team, not exceeding four, can be students from different branches, if the design problem is interdisciplinary.

Expected outcomes of this course are that the students will be able to:

i. Think innovatively on the development of components, products, processes or technologies in the engineering field

ii. Analyse the problem requirements and arrive workable design solutions

The faculty mentors may refer to the Design Thinking literature [9-18]

Faculty mentors are given the autonomy in choosing the topics for the design project. However, it will be better if the mentors are able to inculcate the tenets of design thinking, based on the ideas of empathy for the user. It will be highly appreciable if the projects are in line with the sustainable development goals.

\section{B. Tech. Final Project}

In order to promote innovation and enterprise among the students and to increase the number of patents, publications and industry relevant products emanating from undergraduate student projects from affiliated colleges, the University had initially pondered the possibility of making one full semester available for the final project. However, presently, eighteen hours per week is allotted to the students for the project work. However, with the slots for microprojects and design projects in earlier semesters, careful planning in the initial semesters with proper mentoring from the faculty members can enable the students to obtain high quality output leading to possible publications, patents or industry ready products at the end of the final semester.

\section{Comprehensive Examination}

In order to assess the comprehensive knowledge gained by the students in basic courses associated with the branch of study, the University has introduced a comprehensive examination in the sixth semester of the UG programmes in Engineering. The comprehensive examination is scheduled towards the end of the sixth semester so as to benefit the students who might be appearing for placements and other competitive examinations during the final year. The objective is to prepare the students to comprehend the questions and answer with confidence. Assessment method consists of oral and written examination. Oral examination for 50 marks is to be conducted during weekly during the slot allotted for the course in the curriculum (three students/hour).

Written examination has to be conducted by the department immediately after the second internal examination as a common examination to all students of the same branch. For the sake of convenience, the examination can be of objective type with 1 hour duration covering all the courses up to and including semester V.

Both oral and written examinations are mandatory. But separate minimum marks is not insisted for pass. If a student does not complete any of the two assessments, grade I shall be awarded and the final grade shall be given only after the completion of both the assessments. Two hours allotted for the course may be used by the students as library hours [6]. 
Minor in Engineering

APJ Abdul Kalam Technological University, Kerala offers Minor specialisation in B. Tech degree programme. Students without backlogs are eligible to apply for minor specialisation. They have to earn twelve additional credits in the area of specialisation for the minor degree. For attaining the twelve Credits they should undergo minimum four courses of three credits each during the specified period. The course curriculum is aligned with National Skills Qualifications Framework (NSQF) as specified by the Government of India [19]. Out of the four prescribed courses it is suggested that two courses must be of "Level 4", one course of "Level 5" and one course of "Level 6". The students can avail one year break of study to complete the courses. A detailed framework is approved for implementation of this programme.

\section{B. Tech. (Honours)}

Colleges affiliated to the university with at least two National Board of Accreditation (NBA) accredited programmes can offer $\mathrm{B}$. Tech (Honours) in branches where at least one $\mathrm{M}$. Tech programme is conducted. Students having no credit arrears and CGPA of 8 or above at the end of the fourth semester are eligible to register for B. Tech (Honours) in the beginning of fifth semester. They have to earn additional twelve credits by registering for four courses of three credits each. Of these twelve credits, six credits are to be earned from $M$. Tech courses offered by the concerned department. Remaining credits can be earned from additional $\mathrm{B}$. Tech elective courses, approved MOOC or summer program/project done in IITs or IISc. If a student fails in any course or if the final CGPA falls below 8 , then he/she will not be eligible for B. Tech (Hons.) and will automatically fall back to the $\mathrm{B}$. Tech programme [20].

\section{Break in Study}

In order to promote the entrepreneurial pursuits of the students, the University has introduced the provision for a break of study spanning two semesters, preferably in one academic year, after the student has successfully completed the first four semesters. The student should submit the detailed proposal for the start-up venture, product development etc. to the head of the institution, who in turn, can assess and approve the same and report to the University for approval. In such cases, however, the maximum duration for completing the $\mathrm{B}$. Tech. program will be twelve months.

\section{Summary}

The curriculum of the undergraduate programs of APJ Abdul Kalam Technological University was prepared with the focus on grooming future entrepreneurs and leaders of the industry. The novel list of recommendations are summarised as follows:

Two new courses in first year; Introduction to Sustainable Engineering for enlighten the students about the importance of sustainable development and enable them to pay attention to sustainability aspects for the projects undertaken by them both as students and later as professionals. Design and Engineering shall expose the students to the exciting possibilities of creative and engineering design early, thereby prepare them to learn the higher courses with more interest.

A course on life skills, to create the awareness and assist the students to grow into a well-rounded professional.

Micro-projects, for sustaining the interest of students with experience of executing science or social science projects from their school days and to generate interest among the rest of the students for projects based learning. Remedial courses to assist the students lacking some of the skills or knowledge required for pursuing the program.

Practical courses associated with every course in first year to help the students learn theoretical concepts through practical examples.

Activity points to incentivise and encourage students to engage in co-curricular and extracurricular activities and thereby develop leadership qualities and team work among them.

Design project in fifth semester as a continuation of the project based learning starting with the microprojects in the first year and as a preparation for the final project providing more time to come up with socially or industry relevant projects.

Allocating more time for the B. Tech. final project so as to enable the students complete with same with more visible and productive outcomes such as publications or patents. 
Comprehensive examination during pre-final year to help the students to have a self-awareness about their academic knowledge and also to assist them to prepare better for placement tests and competitive examinations likely to be taken during the final year.

Minor program in Engineering to allow the students to gain interdisciplinary experience and exposure to concepts that may not be a part of their degree programs, thus widening their understanding and better equip them to perform interdisciplinary research.

Break in study for entrepreneurial pursuits for deserving students.

The authors were part of the core team in preparing the draft for the initiatives and leading the discussions on the same with the stakeholders. In the rapidly changing industrial environments and learning needs of the millennium learners, the curriculum reforms in technical education have to be a continuous and regular process. The authors expect regular review and reforms of these initiatives with positive intents for the betterment of technical education in the state.

\section{References}

[1] Singh, H., Malhotra, R. and Rassewatt, K., Qualitative Assessment for Improvement of Technical Education Using Total Quality Management: A Survey, International Research Journal of Engineering and Technology, Vol. 02 Issue 06, Sep., 2015.

[2] Economic Review 2016, State Planning Board, $\mathrm{K}$ e ra $1 \mathrm{a}, \mathrm{Ch}$ a p te r 4, ( $\left.\begin{array}{llll}2 & 0 & 1 & 6\end{array}\right)$, http://spb.kerala.gov.in/EconomicReview2016/ web/chapter04_05

[3] John, A. K., Suryan, A., Rahman, M. A. and Isaac, K. P. (2016), Transforming Kerala-Role of University in Building Entrepreneurship, Journal of Engineering Education Transformations, 29(3), 118-123.

[4] APJ Abdul Kalam Technological University, Curriculum for S1 and S2, B. Tech. 2016, from https://ktu.edu.in/

[5] Belu R., Chiou R., Ciocal. L., Tseng B., (2016), Incorporating Sustainability Concepts and Green Design into Engineering and Technology
Curricula. Journal of Education and Learning. Vol. 10 (2) pp. 93-102.

[6] APJ Abdul Kalam Technological University, Curriculum for S3 to S8, B. Tech. 2016, from https://ktu.edu.in/

[7] Belkin, D., (2015), Skills Gap found in College Students. The Wall Street Journal, p. A5.

[8] APJ Abdul Kalam Technological University, Academic Hand Book, 2016

[9] Kosky, P., Balmer, R., Keat, W., Wise, G., (2016), Exploring Engineering, 4th Edition, An Introduction to Engineering and Design, eBook ISBN: 9780128025888

[10] Dym, C. L., (2013), Engineering Design: A Project-Based Introduction, 4th Edition, Wiley, ISBN:978-1-118-32458-5.

[11] 11. Charles M. (Ed.), (1996), Design for X, Concurrent Engineering Imperatives, Eastman, Springer.

[12] Luchs, M., Swan, S., Griffin, A., (2015), Design Thinking, John Wiley and Sons.

[13] 13. Foster, M. K., (2019), Design Thinking: A Creative Approach to Problem Solving, Management Teaching Review, https://doi.org/10.1177/2379298119871468

[14] Brown, T. (2008), Design Thinking, Harvard Business Review, 86(6), 84-92.

[15] Dam, R., Siang, T., (2018), Five stages in the design thinking process. Retrieved from h t t p s : / / w w w. i n t e r a c t i o n design.org/literature/article/5-stages-in-thedesign-thinking-process

[16] IDEO, (2012), Design thinking for educators: $\mathrm{T}$ o o $1 \mathrm{kit}, \mathrm{R}$ e t r i e ved from: https://designthinkingforeducators.com/toolkit/

[17] Meinel, C., Leifer, L. (2012), Design Thinking Research. In Plattner, H., Meinel, C., Leifer, L. ( E d s . ), D e s i g n T h i n k n g : Understand-Improve-Apply (pp. xiii-xxi). Heidelberg, Germany: Springer. 
[18] Razzouk, R., Shute, V. (2012), What is Design Thinking and Why is it Important? Review of Educational Research, 82, 330-348. doi:10.3102/0034654312457429

[19] https://www.nsda.gov.in/nsqf.html
[20] APJ Abdul Kalam Technological University, Ordinance for Bachelor of Technology and Amendments, B. Tech. / B. Tech. (Honours), from https://ktu.edu.in/ 